\title{
Xenia and metaxenia affects bioactive compounds of hazelnut
}

\author{
Huseyin Irfan Balik (D) 1*, Neriman Beyhan (D)2 \\ ${ }^{1}$ Sakarya University of Applied Science, Faculty of Agriculture, Department of Horticulture, Sakarya-Turkey \\ ${ }^{2}$ Ondokuz Mayıs University Faculty of Agriculture, Department of Horticulture, Samsun-Turkey
}

\begin{abstract}
The study aimed to assess the effects of pollinator cultivars on the bioactive compounds of hazelnut cultivars. 'Tombul', 'Palaz', 'Çakıldak', 'Foşa' and 'Allahverdi' were used as the main cultivars and 'Sivri', 'Kalınkara' and 'Yassı Badem' were used as the pollinators. Self-pollination was accepted as control. It was determined that pollinator cultivars resulted in significant changes in oil and protein ratios and fatty acid composition of hazelnut cultivars mostly because of xenia and metaxenia effects. Protein content and oil content changed depending on pollinator cultivar. The oleic acid was the dominant fatty acid in all hazelnut cultivars.
\end{abstract}

\section{ARTICLE HISTORY}

Received: 18 September 2020

Accepted: 27 September 2020

\section{KEYWORDS}

Corylus avellana

Pollinator

Oil

Protein

Fatty acid composition

* CORRESPONDING

h.irfanbalik@gmail.com

\section{Introduction}

Turkey with about 700000 ha production area is the leading hazelnut producing country of the world and constitutes about $75 \%$ of the world hazelnut production sites. With regard to production sites, Turkey is respectively, followed by Italy with 75000 ha, Azerbaijan with 32000 ha, and Iran with 18000 ha. Turkey with 567000 tons of annual production constitutes about $65 \%$ of world total hazelnut production and, followed by Italy with 106000 tons, the USA with 34000 tons and Azerbaijan with 34.000 tons (Anonymous, 2018a).

Hazelnut has an important place in human nutrition. A $100 \mathrm{~g}$ hazelnut provides $634 \mathrm{kcal}$ energy (Baysal, 1993). Hazelnut has a carbohydrate ratio of between 10-22\%. About 2.8-7.9\% of dry matter is composed of total sugar (Botta et al., 1994). About $90 \%$ of the total sugar is composed of sucrose. Glucose and fructose have only a $15 \%$ ratio. Around $1-3.6 \%$ of dry matter is composed of starch (Anonymous, $2018 \mathrm{~b}$ ). The protein ratio is between $10-24 \%$ and $100 \mathrm{~g}$ hazelnut meets about $22 \%$ of the daily protein need of an individual (Pala et al., 1996). Hazelnut oil has quite high unsaturated fat content, thus reduces blood cholesterol levels. Hazelnut has an oil content of between 50-70\%. Oleic acid is the dominant fatty acid and, followed by linoleic, palmitic, stearic and linolenic acid (Garcia et al., 1994). Oleic acid also reduces blood cholesterol levels and linoleic acid reduces arteriosclerosis. Linoleic and linolenic acid also reduce blood fat and glycerol levels, thus play an active role in controlling hypertension (Kayahan, 1981). Hazelnut oil does not contain cholesterol, which is the primary reason for cardiovascular diseases. Hazelnut contains $1-3.4 \%$ ash and it is an important source of minerals. A $100 \mathrm{~g}$ hazelnut can meet the daily $\mathrm{Fe}, \mathrm{Mg}, \mathrm{Cu}, \mathrm{Mn}, \mathrm{K}, \mathrm{P}, \mathrm{Zn}$ and $\mathrm{Ca}$ needs of an adult (Köksal, 2002).
Pollination and fertilization are the essential processes of the nut set in hazelnuts. Male and female flowers mature and blossom at different times. Blossoming time and duration of male and female flowers vary based on ecology, cultivar and years for the same cultivar (Beyhan, 2000). There are both self-incompatibility and cross-incompatibility in hazelnuts. Previous studies revealed the $33 \mathrm{~S}$ alleles as the reason of self-incompatibility in hazelnuts (Mehlenbacher, 2014).

The dichogamy and incompatibility mechanisms of hazelnuts can be overcome with the use of pollinator cultivars. Previous pollinator cultivar studies revealed that cross-pollination improved nut set and reduced blank nuts. Besides, pollinator cultivars also influence nut quality attributes through xenia and metaxenia effects (Balik and Beyhan, 2019).

Various researchers have made different definitions of xenia and metaxenia (Kirkpatrick, 1987; Morris, 1976; Neufeldt, 1988; Reiger et al., 1976; Soule, 1985; Westwood, 1989; Winburne, 1962). Xenia was the first defined by Focke (1881) as the pollen-induced changes in mother tissues. Swingle (1928) defined xenia as the pollen-induced changes in embryo and endosperm and metaxenia as the polleninduced changes in mother tissues. Denney (1992) defined xenia as pollen-induced changes in seed and fruit shape, color, ripening time and chemical composition. The conceptual confusion about xenia and metaxenia was better elucidated by Strasburger (1878) and Navaschin (1898) with the invention of double-fertilization. Both researchers defined double-fertilization as the fertilization of the ovule in the embryonic sack with one of the male gamete and fertilization of the polar nuclei by the other male gamete. With the invention of double-fertilization, it was proved that it resulted in alterations in endosperm through the pollen effect. Then, following the invention of double-fertilization, xenia was envisaged as the pollen-induced changes in the 
embryo, endosperm and entire mother tissue. Metaxenia has lost the validity, but whether xenia and metaxenia were different phenomena is still being argued by the researchers.

Fatahi et al (2014), indicated that pollinator cultivars influenced nut set and blank nut ratios in hazelnuts. Golzari et al (2016), reported significant effects of pollinators on kernel diameter, weight, shell thickness, oil and protein ratios of walnuts. In Kodad and Company (2008), Dicenta et al (2000) indicated that pollinator cultivars did not alter the taste in almonds significantly. Dure (1975) indicated that the nutritional status of the plant during the embryogenesis influenced the nutritional values of the fruit, Saura Calixto et al (1988) indicated that oil accumulation was realized when the cotyledons matured. Along with these literature, it can be stated that the oil content and composition of the nut were influenced by both the main cultivars and pollinator cultivars. Vezvaei and Jackson (1995) were not able to identify any significant changes in the biochemical composition of 'Nonpareil' almond cultivar with different pollinators. In other plant species, for instance, in maize, pollen source mostly altered endosperm biochemical composition and partially altered embryo biochemical composition (Kodad and Company, 2008).

Kodad and Company (2008), indicated that pollinator cultivars not only altered biochemical composition of walnut but also altered nut and kernel weights. However, changes in the other physical properties were not found to be significant. Self-pollination reduced kernel weight and sizes, oil ratio and linoleic acid content, but increased oleic acid ratios.
Researchers indicated such changes in fatty acids as the factors improving kernel quality. High oleic/linoleic acid ratios indicate oil stability and resistance against spoilage Kester et al (1993) and nutritional value (Vezvaei and Jackson, 1996).

Xuhui et al (2016), reported significant differences in harvest time, nut set, nut and kernel size, sugar, oil, protein, amylase, and vitamin $\mathrm{C}$ contents with different pollinators in chestnuts. Effects of pollinator cultivars on kernel ratio, total starch and moisture content were not found to be significant.

In this study, the effects of self-pollination and different pollinator cultivars on oil and protein ratio and fatty acid composition of the hazelnuts were investigated. Such a study was conducted for the first time in hazelnut.

\section{Materials and methods}

This study was conducted under the ecological conditions of Giresun province in the years 2015 and 2016. The experimental orchard was established in multi-bushed system (Ocak system) at 3x3 m spacing in 1994. 'Tombul', 'Palaz', 'Çakıldak', 'Foşa' and 'Allahverdi' cultivars were used as main cultivars. Self-pollination was practiced. These cultivars were controlled-pollinated with 'Sivri', 'Kalınkara' and 'Yassı Badem' cultivars (Table 1). Experiments were conducted in randomized block design with 3 replications and with 3 plants (bushes) in each replicate. Self-pollination was accepted as the control treatment.

Table 1. Characteristics of hazelnut cultivars

\begin{tabular}{|c|c|c|c|c|}
\hline Cultivar & $\begin{array}{l}\text { Registered } \\
\text { date }\end{array}$ & Pedigree & Nut shape & Traits \\
\hline Tombul & 1990 & Selection of Corylus avellana & Globular & $\begin{array}{l}\text { Excellent kernel quality } \\
\text { kernel market }\end{array}$ \\
\hline Palaz & 1990 & Selection of Corylus avellana & Globular & $\begin{array}{l}\text { Excellent kernel quality } \\
\text { kernel market } \\
\text { susceptible of insects }\end{array}$ \\
\hline Çakıldak & 1990 & Selection of Corylus avellana & Ovoid & $\begin{array}{l}\text { Late bud burst } \\
\text { Low vigor tree }\end{array}$ \\
\hline Foşa & 1990 & Selection of Corylus avellana & Conical & $\begin{array}{l}\text { High vigor tree } \\
\text { High yield }\end{array}$ \\
\hline Allahverdi & 2015 & Selection of Corylus avellana & Ovoid & $\begin{array}{l}\text { Late bud burst } \\
\text { Low kernel percentage }\end{array}$ \\
\hline Sivri & 1990 & Selection of Corylus avellana & Ovoid & susceptible of drought \\
\hline Kalınkara & 1990 & Selection of Corylus avellana & Ovoid & Excellent pollinizer \\
\hline Yass1 Badem & 1990 & Selection of Corylus avellana & Long sub-cylindrical & Early harvest \\
\hline
\end{tabular}

\subsection{Emasculation, isolation and pollen collection}

In plants of the main cultivars to be controlled-hybridized, male flowers (catkins) were removed as specified by Erdoğan and Mehlenbacher (1997).

Plants of the main cultivars were surrounded by $4 \mathrm{~m}$ high and $4 \mathrm{~m}$ wide iron constructions and the entire plant was encapsulated within this framework and covered with Tyvek. When the catkins of pollinator cultivars started to be elongated, they were carefully cut together with the shoot bearing catkins, they were placed in water-filled glass jars and kept at room temperature for $24 \mathrm{~h}$. Each cultivar was kept in different rooms to prevent interactions of pollens. Following $24 \mathrm{~h}$, catkins were shaken over a black paper, pollens were sieved through $125 \mu$ sieve and transferred to preservation cups. Pollens were preserved in a deep freezer at $-18^{\circ} \mathrm{C}$ until the time of hybridization.

\subsection{Controlled pollinations}

When the female flowers of the main cultivars turned into receptive status, pollens preserved in the deep freezer were used to perform hybridizations. Stigmatic styles can accept pollens as soon as they went out of florets, but it waited until these styles got a shiny red color for effective pollination. The pollens stored in preservation cups in a deep freezer were transferred to eppendorph tubes on the day of pollination. Lid of eppendorph tube was opened, the tube turned upside down and flower pollens were taken over the 
index finger. Then artificial pollination was performed through touching to styles of the florets with the index finger. One week after hybridizations, browning was observed in styles.

\subsection{Crude oil (\%)}

The total oil content of hazelnut kernels was determined by the Weende analysis method and expressed as the percentage of dry matter (Ayfer et al., 1986).

\subsection{Protein (\%)}

Nitrogen content of ground kernels was determined with the aid of Kjheldal method and resultant value was multiplied by 6.25 to get the protein ratio $(\mathrm{N} x$ 6.25) (Özenç et al., 2015).

\subsection{Fatty acid composition}

For fatty acid analyses in gas chromatography (GC), initially, fatty acid methyl esters (FAMEs) were prepared from the total oil content of hazelnut through the modified version of the following procedure. At first, $1 \mathrm{ml}$ of total oil was placed into a tube and supplemented with $2 \mathrm{ml} \mathrm{H}_{2} \mathrm{SO}_{4}$ (dissolved in 10\%methanol). The mixture was incubated at $57{ }^{\circ} \mathrm{C}$ and $140 \mathrm{rpm}$ for 40 minutes and cooled off at room temperature. Incubated samples were supplemented with 1 $\mathrm{ml} \mathrm{NaHCO}_{3} \quad(2 \%)$ and vortexed. Following vortexing, samples were supplemented with $1 \mathrm{ml}$ hexane and shaken for a minute. The upper hexane layer including FAMEs was transferred to a new tube and preserved at $-20{ }^{\circ} \mathrm{C}$ for further GC analyses. Samples were filtered through a $0.2 \mu \mathrm{m}$ nylon membrane filter and analyzed in Shimadzu GC-20A (Kyoto, Japan) equipped with flame-ionization detector. In GC analyses, Stabilwax DA column $(0.25 \mathrm{~mm}$ x $0.25 \mu \mathrm{m} 60 \mathrm{~m})$ was used, the flow rate was $3 \mathrm{ml} \mathrm{min}^{-1}$ and carrier gas was nitrogen. The initial column temperature was $100{ }^{\circ} \mathrm{C}$ for 4 minutes and the column was gradually heated up to $245^{\circ} \mathrm{C}$ $\left(20{ }^{\circ} \mathrm{C} / \mathrm{min}\right.$ ) and kept at this temperature for 40 minutes. Then the column temperature was raised to $250{ }^{\circ} \mathrm{C}$ and hold at that temperature for $5 \mathrm{~min}$. Split injection (1:20) was performed at $250{ }^{\circ} \mathrm{C}$. Fatty acid peaks were defined by reference standards comparing retention times. The results were processed with the aid of "GC Solution" software supplied by the manufacturer of the GC and relative percentages of fatty acids were identified.

\subsection{Statistical analysis}

Experimental data were subjected to statistical analyses with the aid of SAS Version 9.1 software. Data were subjected to analysis of variance separately for each year. Treatments means were separated by Duncan's multiple range test $(\mathrm{P}<0.05)$.

Table 2. Oil ratios in hybridization combinations in 2015 and 2016 (\%)

\begin{tabular}{|c|c|c|c|c|c|}
\hline \multirow{3}{*}{$\begin{array}{l}\text { Pollinator } \\
\text { cultivars }\end{array}$} & \multicolumn{5}{|c|}{ Main cultivars } \\
\hline & \multicolumn{5}{|c|}{2015} \\
\hline & Tombul & Palaz & Çakıldak & Foşa & Allahverdi \\
\hline Tombul & $62.97 \mathrm{~cd}$ & $59.16 \mathrm{~d}$ & $62.18 \mathrm{c}$ & $62.26 \mathrm{ab}$ & $63.94 \mathrm{c}$ \\
\hline Palaz & $65.89 \mathrm{ab}$ & $* *$ & $62.52 \mathrm{bc}$ & $* *$ & $65.74 \mathrm{a}$ \\
\hline Çakıldak & $65.37 \mathrm{~b}$ & $61.26 \mathrm{~b}$ & $* *$ & $63.61 \mathrm{a}$ & $61.05 \mathrm{f}$ \\
\hline Foşa & $62.02 \mathrm{~d}$ & $62.51 \mathrm{a}$ & $63.17 \mathrm{~b}$ & $58.88 \mathrm{c}$ & $63.07 \mathrm{e}$ \\
\hline Allahverdi & $65.22 \mathrm{~b}$ & $62.75 \mathrm{a}$ & $62.95 \mathrm{bc}$ & $63.25 \mathrm{ab}$ & $64.55 \mathrm{~b}$ \\
\hline Sivri & $63.83 \mathrm{c}$ & $* *$ & $63.05 \mathrm{~b}$ & $61.80 \mathrm{~b}$ & $63.48 \mathrm{~d}$ \\
\hline Kalınkara & $66.63 \mathrm{a}$ & $* *$ & $63.18 \mathrm{~b}$ & $* *$ & $64.20 \mathrm{bc}$ \\
\hline \multirow[t]{2}{*}{ Yassı Badem } & $63.74 \mathrm{c}$ & $61.13 \mathrm{bc}$ & $64.43 \mathrm{a}$ & $* *$ & $64.45 \mathrm{~b}$ \\
\hline & \multicolumn{5}{|c|}{2016} \\
\hline Tombul & $63.33 \mathrm{ab}$ & $57.00 \mathrm{de}$ & $51.50 \mathrm{~cd}$ & $68.42 \mathrm{a}$ & $59.08 \mathrm{c}$ \\
\hline Palaz & $62.55 \mathrm{ab}$ & $* *$ & $59.25 \mathrm{a}$ & $60.25 \mathrm{bcd}$ & $61.25 b c$ \\
\hline Çakıldak & $57.47 \mathrm{~d}$ & $62.33 \mathrm{ab}$ & $51.25 \mathrm{~d}$ & $62.42 \mathrm{~b}$ & $66.00 \mathrm{a}$ \\
\hline Foşa & $57.85 \mathrm{~cd}$ & $61.50 \mathrm{abc}$ & $57.25 \mathrm{ab}$ & $53.90 \mathrm{e}$ & $52.50 \mathrm{~d}$ \\
\hline Allahverdi & $66.00 \mathrm{a}$ & $64.00 \mathrm{a}$ & $61.17 \mathrm{a}$ & $58.67 \mathrm{~cd}$ & $63.25 \mathrm{ab}$ \\
\hline Sivri & $61.42 \mathrm{bc}$ & $60.00 \mathrm{bcd}$ & $59.17 \mathrm{a}$ & $63.00 \mathrm{~b}$ & $62.67 \mathrm{~b}$ \\
\hline Kalınkara & $61.00 \mathrm{bc}$ & $65.08 \mathrm{a}$ & $58.33 \mathrm{ab}$ & $61.58 \mathrm{bcd}$ & $62.50 \mathrm{~b}$ \\
\hline Yassı Badem & $61.42 \mathrm{bc}$ & $55.08 \mathrm{e}$ & $55.00 \mathrm{bc}$ & $62.00 \mathrm{bc}$ & $60.67 \mathrm{bc}$ \\
\hline
\end{tabular}

*The means indicated with the same letter in the same column are not significantly different at $\mathrm{P}<0.05$. **: Data missing.

\section{Results and discussion}

\subsection{Oil ratio}

The effects of pollinators on oil ratios were found to be significant in both years of the experiments $(\mathrm{P}<0.05)$. 'Foşa' cultivars in 2015 and 2016 had lower oil ratios in selfpollination treatments than in the other treatments (Table 2). Kodad and Company (2008) reported decreased oil ratios with self-pollination treatments in almonds.

Balik et al. (2016) investigated the oil ratios of important hazelnut cultivars of Turkey and reported the values as $59.8 \%$ for 'Tombul', $61.0 \%$ for 'Palaz', 59.4\% for
'Çakıldak', 58.3\% for 'Foşa' and 58.0\% for 'Allahverdi' cultivars. Köksal (2002) reported the oil ratio as $64.6 \%$ for 'Tombul', 57.7\% for 'Palaz', 61.0\% for 'Çakıldak' and $59.5 \%$ for 'Foşa' cultivars. Okay et al. (1999) reported the oil ratio of 'Allahverdi' cultivar as $62.5 \%$. Present findings on oil ratios comply with the results of those previous study. Kodad and Company (2008) and Saura Calixto et al. (1988) indicated oil accumulation when the cotyledons were ripened, thus both the main and pollinator cultivars had significant effects on kernel oil ratios and fatty acid composition. It was indicated in previous studies that pollinators significantly altered oil ratios and fatty acid 
composition in chestnut (Xuhui et al., 2016) and walnut (Golzari et al., 2016).

\subsection{Protein ratio}

The effects of treatments on protein ratios were found to be significant in both years of the experiments (Table 3). Balik et al. (2016) reported the protein ratio as $17.07 \%$ for 'Tombul', 17.36\% for 'Palaz', 17.55\% for 'Çakıldak',
$18.64 \%$ for 'Foşa' and 19.53\% for 'Allahverdi' cultivars. Köksal (2002) reported protein ratio as $17.51 \%$ for 'Tombul', 18.03\% for 'Palaz', 19.44\% for 'Çakıldak' and $15.75 \%$ for 'Foşa' cultivars. Okay et al. (1999) reported protein ratio of 'Allahverdi' cultivar as $14.67 \%$. It was reported in previous studies that pollinators significantly altered protein ratios in walnut (Golzari et al., 2016) and chestnut (Xuhui et al., 2016).

Table 3. Protein ratios in hybridization combinations in 2015 and 2016 (\%)

\begin{tabular}{|c|c|c|c|c|c|}
\hline \multirow{3}{*}{$\begin{array}{l}\text { Pollinator } \\
\text { cultivars }\end{array}$} & \multicolumn{5}{|c|}{ Main cultivars } \\
\hline & \multicolumn{5}{|c|}{2015} \\
\hline & Tombul & Palaz & Çakıldak & Foşa & Allahverdi \\
\hline Tombul & $17.47 \mathrm{ab}$ & $18.46 \mathrm{a}$ & $18.02 \mathrm{~b}$ & $17.48 \mathrm{a}$ & $17.30 \mathrm{ab}$ \\
\hline Palaz & $17.02 \mathrm{bc}$ & $* *$ & $16.89 \mathrm{~d}$ & ** & $17.66 \mathrm{a}$ \\
\hline Çakıldak & $17.05 \mathrm{bc}$ & $17.40 \mathrm{~b}$ & $* *$ & $14.66 \mathrm{c}$ & $17.20 \mathrm{ab}$ \\
\hline Foşa & $16.73 \mathrm{~cd}$ & $15.75 \mathrm{~d}$ & $16.17 \mathrm{e}$ & $16.30 \mathrm{~b}$ & $17.28 \mathrm{ab}$ \\
\hline Allahverdi & $16.53 \mathrm{~cd}$ & $16.77 \mathrm{c}$ & $17.46 \mathrm{c}$ & $16.30 \mathrm{~b}$ & $17.92 \mathrm{a}$ \\
\hline Sivri & $17.30 \mathrm{ab}$ & $* *$ & $16.90 \mathrm{~d}$ & $16.12 \mathrm{~b}$ & $17.58 \mathrm{a}$ \\
\hline Kalınkara & $16.27 \mathrm{~d}$ & $* *$ & $19.07 \mathrm{a}$ & $* *$ & $17.80 \mathrm{a}$ \\
\hline \multirow[t]{2}{*}{ Yassı Badem } & $17.80 \mathrm{a}$ & $18.04 \mathrm{a}$ & $15.47 \mathrm{f}$ & $* *$ & $16.74 \mathrm{~b}$ \\
\hline & \multicolumn{5}{|c|}{2016} \\
\hline Tombul & $18.32 \mathrm{~b}$ & $17.70 \mathrm{a}$ & $19.30 \mathrm{~b}$ & $16.96 \mathrm{~cd}$ & $16.19 \mathrm{~d}$ \\
\hline Palaz & $16.67 \mathrm{~d}$ & $* *$ & $16.87 \mathrm{e}$ & $16.50 \mathrm{ef}$ & $17.29 \mathrm{c}$ \\
\hline Çakıldak & $17.42 \mathrm{c}$ & $14.48 \mathrm{e}$ & $20.21 \mathrm{a}$ & $16.71 \mathrm{de}$ & $17.04 \mathrm{c}$ \\
\hline Foşa & $16.42 \mathrm{e}$ & $15.34 \mathrm{bc}$ & $16.28 \mathrm{f}$ & $15.71 \mathrm{~g}$ & $19.58 \mathrm{a}$ \\
\hline Allahverdi & $17.66 \mathrm{c}$ & $14.96 \mathrm{~d}$ & $16.40 \mathrm{f}$ & $18.08 \mathrm{~b}$ & $15.64 \mathrm{e}$ \\
\hline Sivri & $19.49 \mathrm{a}$ & $15.30 \mathrm{bcd}$ & $18.17 \mathrm{c}$ & $18.82 \mathrm{a}$ & $17.91 \mathrm{~b}$ \\
\hline Kalınkara & $18.18 \mathrm{~b}$ & $15.23 \mathrm{~cd}$ & $16.90 \mathrm{e}$ & $16.11 \mathrm{f}$ & $16.07 \mathrm{~d}$ \\
\hline Yassı Badem & $15.80 \mathrm{f}$ & $15.20 \mathrm{~cd}$ & $17.08 \mathrm{de}$ & $16.32 \mathrm{ef}$ & $16.17 \mathrm{~d}$ \\
\hline
\end{tabular}

*The means indicated with the same letter in the same column are not significantly different at $\mathrm{P}<0.05$. **: Data missing.

\subsection{Oleic acid (C 18:1)}

Experimental treatments had significant effects on oleic acid content in both years of the experiments $(\mathrm{P}<0.05)$. In 'Palaz', 'Çakıldak', 'Foşa' and 'Allahverdi' cultivars oleic acid was

found to be lower in self-pollination than in other treatments in 2015. However, in 2016, a similar case was observed only in 'Palaz' and 'Çakıldak' cultivars (Table 4).

Table 4. Oleic acid (C18:1) in hybridization combinations in 2015 and 2016 (\%)

\begin{tabular}{|c|c|c|c|c|c|}
\hline \multirow{3}{*}{$\begin{array}{l}\text { Pollinator } \\
\text { cultivars }\end{array}$} & \multicolumn{5}{|c|}{ Main cultivars } \\
\hline & \multicolumn{5}{|c|}{2015} \\
\hline & Tombul & Palaz & Çakıldak & Foşa & Allahverdi \\
\hline Tombul & $75.06 \mathrm{c}$ & $75.41 \mathrm{~b}$ & $74.44 \mathrm{~g}$ & $75.78 \mathrm{ab}$ & $75.39 \mathrm{de}$ \\
\hline Palaz & $75.70 \mathrm{a}$ & $77.77 \mathrm{a}$ & $75.27 \mathrm{e}$ & $60.16 \mathrm{c}$ & $76.60 \mathrm{~b}$ \\
\hline Çakıldak & $67.69 \mathrm{~g}$ & $77.29 \mathrm{a}$ & $77.15 \mathrm{a}$ & $69.96 \mathrm{~b}$ & $74.96 \mathrm{e}$ \\
\hline Foşa & 74.17 ef & $77.12 \mathrm{a}$ & $75.65 \mathrm{c}$ & $77.12 \mathrm{a}$ & $76.45 \mathrm{bc}$ \\
\hline Allahverdi & $74.03 \mathrm{f}$ & $75.50 \mathrm{~b}$ & $75.44 \mathrm{~d}$ & $77.23 \mathrm{a}$ & $77.47 \mathrm{a}$ \\
\hline Sivri & $74.54 \mathrm{~d}$ & $75.93 \mathrm{~b}$ & $74.64 \mathrm{f}$ & $76.72 \mathrm{a}$ & $75.90 \mathrm{~cd}$ \\
\hline Kalınkara & $74.34 \mathrm{de}$ & $* *$ & $75.22 \mathrm{e}$ & $76.06 \mathrm{a}$ & $77.31 \mathrm{a}$ \\
\hline \multirow[t]{2}{*}{ Yassı Badem } & $75.32 \mathrm{~b}$ & $77.52 \mathrm{a}$ & $75.91 \mathrm{~b}$ & $77.28 \mathrm{a}$ & $75.52 \mathrm{de}$ \\
\hline & \multicolumn{5}{|c|}{2016} \\
\hline Tombul & $59.86 \mathrm{~h}$ & $66.52 \mathrm{ab}$ & $67.56 \mathrm{bc}$ & $67.24 \mathrm{~d}$ & $66.19 \mathrm{~g}$ \\
\hline Palaz & $64.82 \mathrm{~d}$ & $66.18 \mathrm{ab}$ & $72.81 \mathrm{a}$ & $76.58 \mathrm{a}$ & $67.30 \mathrm{~d}$ \\
\hline Çakıldak & $75.15 \mathrm{a}$ & $67.08 \mathrm{a}$ & $73.11 \mathrm{a}$ & $76.59 \mathrm{a}$ & $66.44 \mathrm{f}$ \\
\hline Foşa & $68.26 \mathrm{c}$ & $63.97 \mathrm{~b}$ & $66.45 \mathrm{c}$ & $72.71 \mathrm{~b}$ & $67.41 \mathrm{c}$ \\
\hline Allahverdi & $62.47 \mathrm{f}$ & $68.05 \mathrm{a}$ & $68.35 \mathrm{~b}$ & $69.52 \mathrm{c}$ & $67.05 \mathrm{e}$ \\
\hline Sivri & $61.77 \mathrm{~g}$ & $71.57 \mathrm{a}$ & $67.60 \mathrm{bc}$ & $67.04 \mathrm{~d}$ & $67.69 \mathrm{~b}$ \\
\hline Kalınkara & $63.32 \mathrm{e}$ & $69.01 \mathrm{a}$ & $68.25 \mathrm{bc}$ & $73.26 \mathrm{~b}$ & $68.56 \mathrm{a}$ \\
\hline Yassı Badem & $68.40 \mathrm{~b}$ & $68.30 \mathrm{a}$ & $69.23 \mathrm{~b}$ & $70.56 \mathrm{~b}$ & $64.01 \mathrm{~h}$ \\
\hline
\end{tabular}


and Company (2008) reported decreased linoleic acid ratios, but increasing oleic acid ratios with self-pollination treatments in almond and indicated such changes in fatty acids as the oil-quality improving factors. Köksal (2002) reported oleic acid content as $77.8 \%$ for 'Tombul', $77.6 \%$ for 'Palaz', $80.7 \%$ for 'Çakıldak' and $79.0 \%$ for 'Foşa' cultivars. Koyuncu et al. (2005) reported oleic content as $78.8 \%$ for 'Tombul' and $78.52 \%$ for 'Palaz' cultivars. Balik et al. (2016) worked on standard hazelnut cultivars and reported oleic content as $68.8 \%$ for 'Tombul', $72.6 \%$ for 'Palaz', $67.7 \%$ for 'Çakıldak', $65.7 \%$ for 'Foşa' and $61.7 \%$ for 'Allahverdi' cultivars. Although present oleic acid values generally comply with those earlier ones, some cultivars had low oleic acid contents in 2016. It was indicated in a previous study that nutritional and chemical composition of hazelnut may vary based on cultivar, ecology and cultural practices (Köksal, 2002). Greater oleic/linoleic acid ratios designate oil stability and resistance against degradation (Kester et al., 1993) and nutritional value (Vezvaei and Jackson, 1996).

\subsection{Palmitic acid (C 16:0)}

Effects of treatments on palmitic acid contents were found to be significant in both years of the experiments $(\mathrm{P}<0.05)$. Palmitic acid contents of 2016 were greater than the palmitic acid contents of 2015 (Table 5). Köksal (2002) reported palmitic acid content as $5.17 \%$ for 'Tombul', $4.87 \%$ for 'Palaz', 4.89\% for 'Çakıldak' and 5.62\% for 'Foşa' cultivars. Göncüoğlu and Gökmen (2015) reported palmitic acid content as $6.13 \%$ for 'Tombul', $6.54 \%$ for 'Palaz', $4.59 \%$ for 'Çakı1lak' and 5.69\% for 'Foşa' cultivars. Balik et al. (2016) reported palmitic acid content of standard hazelnut cultivars as $10.24 \%$ for 'Tombul', 9.99\% for 'Palaz', $10.0 \%$ for 'Çakıldak', 9.68\% for 'Foşa' and $13.0 \%$ for 'Allahverdi' cultivars. Present palmitic acid contents were lower than the values reported by Köksal (2002) and Göncüoğlu and Gökmen (2015), but similar to the values reported by Balik et al. (2016).

\subsection{Stearic acid (C 18:0)}

Experimental treatments had significant effects on stearic acid contents in both years of the experiments $(\mathrm{P}<0.05)$. The stearic acid contents of the second year were greater than the stearic acid contents of the first year. In 2015, the greatest stearic acid content in 'Tombul', 'Foșa' and 'Allahverdi' cultivars were obtained from 'Çakıldak' pollination treatments however the same case was not valid in the second year. In 2016, low stearic acid contents were observed in self-pollination treatments of all cultivars, except for 'Tombul' (Table 6). Köksal (2002) reported stearic acid contents as $1.75 \%$ for 'Tombul', 2.13\% for 'Palaz', 2.15\% for 'Çakıldak' and $1.70 \%$ for 'Foşa' cultivars. Göncüoğlu and Gökmen (2015) reported stearic acid content as 3.58\% for 'Tombul', 3.08\% for 'Palaz', 4.61\% for 'Çakıldak' and $3.12 \%$ for 'Foşa' cultivars. Balik et al. (2016) also worked on standard hazelnut cultivars and reported stearic acid content as $4.37 \%$ for 'Tombul', $4.52 \%$ for 'Palaz', 3.77\% for 'Çakıldak', 3.81\% for 'Foşa' and 5.12\% for 'Allahverdi' cultivars. Present findings on stearic acid contents were greater than those earlier ones reported in previous literatures.

Table 5. Palmitic acid (C16:0) in hybridization combinations in 2015 and 2016 (\%)

\begin{tabular}{|c|c|c|c|c|c|}
\hline \multirow{3}{*}{$\begin{array}{l}\text { Pollinator } \\
\text { cultivars }\end{array}$} & \multicolumn{5}{|c|}{ Main cultivars } \\
\hline & \multicolumn{5}{|c|}{2015} \\
\hline & Tombul & Palaz & Çakıldak & Foşa & Allahverdi \\
\hline Tombul & $9.16 \mathrm{~b}$ & $8.47 \mathrm{~d}$ & $9.52 \mathrm{~d}$ & $9.20 \mathrm{bcd}$ & $8.77 \mathrm{c}$ \\
\hline Palaz & $8.34 \mathrm{f}$ & $8.76 \mathrm{~cd}$ & $9.58 \mathrm{c}$ & 9.94 b & $9.21 \mathrm{a}$ \\
\hline Çakıldak & $11.26 \mathrm{a}$ & $9.51 \mathrm{a}$ & $9.38 \mathrm{e}$ & $12.39 \mathrm{a}$ & $9.16 \mathrm{a}$ \\
\hline Foşa & $8.87 \mathrm{~d}$ & $9.33 \mathrm{ab}$ & $8.88 \mathrm{~h}$ & $9.46 \mathrm{bc}$ & $9.02 \mathrm{ab}$ \\
\hline Allahverdi & $8.99 \mathrm{c}$ & $9.64 \mathrm{a}$ & $10.13 \mathrm{a}$ & $9.34 \mathrm{bc}$ & $8.82 \mathrm{bc}$ \\
\hline Sivri & $8.90 \mathrm{c}$ & $9.70 \mathrm{a}$ & $9.80 \mathrm{~b}$ & $8.93 \mathrm{~cd}$ & $9.03 \mathrm{ab}$ \\
\hline Kalınkara & $8.31 \mathrm{f}$ & $* *$ & $9.09 \mathrm{~g}$ & $9.46 \mathrm{bc}$ & $9.15 \mathrm{a}$ \\
\hline \multirow[t]{2}{*}{ Yass1 Badem } & $8.53 \mathrm{e}$ & $8.69 \mathrm{c}$ & $9.13 \mathrm{f}$ & $8.91 \mathrm{~cd}$ & $9.02 \mathrm{ab}$ \\
\hline & \multicolumn{5}{|c|}{2016} \\
\hline Tombul & $13.10 \mathrm{a}$ & $11.69 \mathrm{~cd}$ & $11.25 \mathrm{~b}$ & $12.10 \mathrm{a}$ & $11.03 \mathrm{f}$ \\
\hline Palaz & $11.98 \mathrm{~d}$ & $12.12 \mathrm{bcd}$ & $10.53 \mathrm{~b}$ & $9.14 \mathrm{e}$ & $12.29 \mathrm{c}$ \\
\hline Çakıldak & $8.57 \mathrm{~g}$ & $12.99 \mathrm{ab}$ & $11.26 \mathrm{~b}$ & $10.10 \mathrm{de}$ & $12.51 \mathrm{~b}$ \\
\hline Foşa & $10.87 \mathrm{f}$ & $13.92 \mathrm{a}$ & $12.62 \mathrm{a}$ & $11.38 \mathrm{~b}$ & $11.33 \mathrm{e}$ \\
\hline Allahverdi & $12.30 \mathrm{c}$ & $11.96 \mathrm{bcd}$ & $12.72 \mathrm{a}$ & $11.30 \mathrm{bc}$ & $12.32 \mathrm{c}$ \\
\hline Sivri & $12.72 \mathrm{~b}$ & $11.14 \mathrm{bcd}$ & $11.81 \mathrm{~b}$ & $12.19 \mathrm{a}$ & $11.63 \mathrm{~d}$ \\
\hline Kalınkara & $12.00 \mathrm{~d}$ & $11.06 \mathrm{~d}$ & $11.44 \mathrm{~b}$ & $10.70 \mathrm{~cd}$ & $10.93 \mathrm{~g}$ \\
\hline Yassı Badem & $11.04 \mathrm{e}$ & $12.53 \mathrm{bc}$ & $11.82 \mathrm{~b}$ & $11.52 \mathrm{bc}$ & $12.72 \mathrm{a}$ \\
\hline
\end{tabular}

\section{*The means indicated with the sa}

The effects of experimental treatments on linoleic acid contents were found to be significant in both years of the experiments $(\mathrm{P}<0.05)$. Greater linoleic acid contents were observed in 2016 than in 2015. Self-pollination treatments yielded the greatest linoleic acid contents in 'Çakıldak', 'Foşa' and 'Allahverdi' cultivars in 2015 and 'Tombul' and 'Çakıldak' cultivars in 2016 (Table 7). Köksal (2002) reported linoleic acid content as $14.8 \%$ for 'Tombul', $15.0 \%$ for 'Palaz', $11.9 \%$ for 'Çakıldak' and 13.2\% for 'Foşa' cultivars. Göncüoğlu and Gökmen (2015) reported linoleic acid content as $10.11 \%$ for 'Tombul', $7.28 \%$ for 'Palaz', $6.39 \%$ for 'Çakıldak' and $15.99 \%$ for 'Foşa' cultivars. Balik et al. (2016) worked on standard hazelnut cultivars and reported linoleic acid content as $15.57 \%$ for 'Tombul', $12.64 \%$ for 'Palaz', $13.39 \%$ for 'Çakıldak', 20.52\% for 
'Foşa' and $17.84 \%$ for 'Allahverdi' cultivars. Present linoleic acid contents were greater than the earlier ones. Such a case was especially more remarkable in 'Foşa' and 'Allahverdi' cultivars. Bonvehi and Cool (1993) conducted a study about oil contents, stability and fatty acid composition of Catalonia hazelnut cultivars and reported that linoleic acid was the dominant fatty acid in nut set period, oleic acid content increased in ripening period and became the dominant fatty acid.

Table 6. Stearic acid (C18:0) in hybridization combinations in 2015 and 2016 (\%)

\begin{tabular}{|c|c|c|c|c|c|}
\hline \multirow{3}{*}{$\begin{array}{l}\text { Pollinator } \\
\text { cultivars }\end{array}$} & \multicolumn{5}{|c|}{ Main cultivars } \\
\hline & \multicolumn{5}{|c|}{2015} \\
\hline & Tombul & Palaz & Çakıldak & Foşa & Allahverdi \\
\hline Tombul & $7.88 \mathrm{c}$ & 7.84 bc & $7.78 \mathrm{a}$ & $8.15 \mathrm{bcd}$ & $8.44 \mathrm{~b}$ \\
\hline Palaz & $7.14 \mathrm{f}$ & $7.89 \mathrm{~b}$ & $7.58 \mathrm{~b}$ & $8.09 \mathrm{bc}$ & $8.28 \mathrm{c}$ \\
\hline Çakıldak & $9.98 \mathrm{a}$ & $7.44 \mathrm{~d}$ & $6.96 \mathrm{f}$ & $10.96 \mathrm{a}$ & $9.06 \mathrm{a}$ \\
\hline Foşa & $7.90 \mathrm{~d}$ & $7.84 \mathrm{bc}$ & $7.23 \mathrm{~d}$ & $7.61 \mathrm{~cd}$ & $7.92 \mathrm{~d}$ \\
\hline Allahverdi & $7.29 \mathrm{e}$ & 7.59 bcd & $7.22 \mathrm{~d}$ & $7.29 \mathrm{~d}$ & $8.43 \mathrm{~b}$ \\
\hline Sivri & $6.12 \mathrm{~g}$ & $7.52 \mathrm{~cd}$ & $7.08 \mathrm{e}$ & $7.52 \mathrm{~cd}$ & $7.96 \mathrm{~d}$ \\
\hline Kalınkara & $7.76 \mathrm{~d}$ & $* *$ & $7.54 \mathrm{c}$ & $8.62 \mathrm{~b}$ & $7.40 \mathrm{e}$ \\
\hline \multirow[t]{2}{*}{ Yassı Badem } & $8.11 \mathrm{~b}$ & $8.19 \mathrm{a}$ & $6.94 \mathrm{f}$ & $7.39 \mathrm{~cd}$ & 8.37 bc \\
\hline & \multicolumn{5}{|c|}{2016} \\
\hline Tombul & $12.71 \mathrm{a}$ & $11.98 \mathrm{bc}$ & $11.04 \mathrm{ab}$ & $11.41 \mathrm{ab}$ & $10.77 \mathrm{~g}$ \\
\hline Palaz & $11.59 \mathrm{~d}$ & $10.54 \mathrm{de}$ & $8.47 \mathrm{e}$ & $7.94 \mathrm{f}$ & $12.12 \mathrm{c}$ \\
\hline Çakıldak & $7.38 \mathrm{~h}$ & $10.65 \mathrm{de}$ & $9.32 \mathrm{~d}$ & $7.83 \mathrm{f}$ & $12.46 \mathrm{a}$ \\
\hline Foşa & $10.32 \mathrm{f}$ & $13.14 \mathrm{a}$ & $11.23 \mathrm{a}$ & $9.13 \mathrm{e}$ & $11.86 \mathrm{~d}$ \\
\hline Allahverdi & $11.45 \mathrm{e}$ & $10.08 \mathrm{e}$ & $10.47 \mathrm{c}$ & $11.11 \mathrm{bc}$ & $11.55 \mathrm{e}$ \\
\hline Sivri & $12.50 \mathrm{c}$ & $9.19 \mathrm{e}$ & $10.53 b c$ & $11.79 \mathrm{a}$ & $11.18 \mathrm{f}$ \\
\hline Kalınkara & $12.56 \mathrm{~b}$ & $11.09 \mathrm{~cd}$ & $10.23 \mathrm{c}$ & $10.37 \mathrm{~d}$ & $10.27 \mathrm{~h}$ \\
\hline Yassı Badem & $10.01 \mathrm{~g}$ & $11.35 \mathrm{bcd}$ & $9.62 \mathrm{~d}$ & $11.22 \mathrm{~cd}$ & $12.30 \mathrm{~b}$ \\
\hline
\end{tabular}

*The means indicated with the same letter in the same column are not significantly different at $\mathrm{P}<0.05$. **: Data missing.

Table 7. Linoleic acid (C18:2) in hybridization combinations in 2015 and 2016 (\%)

\begin{tabular}{|c|c|c|c|c|c|}
\hline \multirow{3}{*}{$\begin{array}{l}\text { Pollinator } \\
\text { cultivars }\end{array}$} & \multicolumn{5}{|c|}{ Main cultivars } \\
\hline & \multicolumn{5}{|c|}{2015} \\
\hline & Tombul & Palaz & Çakıldak & Foşa & Allahverdi \\
\hline Tombul & $6.23 \mathrm{f}$ & $6.71 \mathrm{a}$ & $5.59 \mathrm{f}$ & $5.57 \mathrm{bc}$ & $7.17 \mathrm{a}$ \\
\hline Palaz & $7.18 \mathrm{e}$ & $4.08 \mathrm{e}$ & $5.07 \mathrm{~g}$ & $4.53 \mathrm{~d}$ & $4.95 \mathrm{f}$ \\
\hline Çakıldak & $8.45 \mathrm{~b}$ & $4.06 \mathrm{e}$ & $5.82 \mathrm{e}$ & $6.40 \mathrm{a}$ & $6.54 \mathrm{~b}$ \\
\hline Foşa & $7.32 \mathrm{~d}$ & $4.47 \mathrm{~d}$ & $6.11 \mathrm{~d}$ & $5.06 \mathrm{~cd}$ & $6.18 \mathrm{~d}$ \\
\hline Allahverdi & $7.82 \mathrm{c}$ & $6.18 \mathrm{~b}$ & $6.49 \mathrm{a}$ & $5.79 \mathrm{~b}$ & $4.90 \mathrm{f}$ \\
\hline Sivri & $8.72 \mathrm{a}$ & $5.30 \mathrm{c}$ & $6.31 \mathrm{c}$ & $6.67 \mathrm{a}$ & $6.79 \mathrm{~b}$ \\
\hline Kalınkara & $7.78 \mathrm{c}$ & $* *$ & $6.37 \mathrm{~b}$ & $5.76 \mathrm{~b}$ & $5.74 \mathrm{e}$ \\
\hline \multirow[t]{2}{*}{ Yassı Badem } & $6.16 \mathrm{~g}$ & $4.56 \mathrm{~d}$ & $5.70 \mathrm{f}$ & $5.16 \mathrm{c}$ & $6.36 \mathrm{c}$ \\
\hline & \multicolumn{5}{|c|}{2016} \\
\hline Tombul & $10.44 \mathrm{~b}$ & $6.75 \mathrm{~b}$ & $6.94 \mathrm{bc}$ & $6.94 \mathrm{~b}$ & $11.75 \mathrm{a}$ \\
\hline Palaz & $8.56 \mathrm{e}$ & $8.66 \mathrm{a}$ & $5.14 \mathrm{f}$ & $5.99 \mathrm{~d}$ & $6.91 \mathrm{~h}$ \\
\hline Çakıldak & $6.93 \mathrm{~h}$ & $6.74 \mathrm{~b}$ & $5.45 \mathrm{e}$ & $5.17 \mathrm{f}$ & $8.06 \mathrm{~g}$ \\
\hline Foşa & $8.29 \mathrm{f}$ & $6.77 \mathrm{~b}$ & $6.00 \mathrm{~d}$ & $5.95 \mathrm{~d}$ & $8.93 \mathrm{~d}$ \\
\hline Allahverdi & $10.92 \mathrm{a}$ & $7.50 \mathrm{a}$ & $7.63 \mathrm{a}$ & $7.79 \mathrm{a}$ & $8.52 \mathrm{f}$ \\
\hline Sivri & $10.00 \mathrm{c}$ & $6.14 \mathrm{~b}$ & $6.66 \mathrm{c}$ & $6.54 \mathrm{c}$ & $8.74 \mathrm{e}$ \\
\hline Kalınkara & $9.20 \mathrm{~d}$ & $5.71 \mathrm{c}$ & $7.35 \mathrm{ab}$ & $5.59 \mathrm{e}$ & $9.84 \mathrm{~b}$ \\
\hline Yassı Badem & $7.92 \mathrm{~g}$ & $5.66 \mathrm{c}$ & $6.05 \mathrm{~d}$ & $4.96 \mathrm{~g}$ & $9.75 \mathrm{c}$ \\
\hline
\end{tabular}

\subsection{Palmitoleic acid (C 16:1)}

Experimental treatments had significant effects on palmitoleic acid contents in both years of the experiments $(\mathrm{P}<0.05)$. Palmitoleic acid values were found higher in 'Tombul', 'Palaz' and 'Çakıldak' cultivars in the second year of the experiment. Palmitoleic acid in 'Tombul' cultivar was found to be the lowest in 'Palaz' pollination treatments in 2015 and 'Çakıldak' pollination treatments in 2016. In the 'Palaz' cultivar, 'Allahverdi' and 'Yassı Badem' pollination treatments in 2015 and 'Foşa', 'Sivri' and 'Yassı Badem' pollination treatments in 2016. In the 'Çakıldak' cultivar, the lowest palmitoleic acid was determined during the two years of the experiment in self-pollination and 'Allahverdi' pollination treatments. Palmitic acid was determined at the lowest level in the case of 'Kalınkara' pollination treatments in the 'Foşa' cultivar and in the 'Tombul' pollination treatments in the 'Allahverdi' cultivar. Greater palmitoleic values of controlled pollinations than the previous literatures may be considered as the effect of pollinators. Köksal (2002) 
reported palmitoleic acid contents as $0.48 \%$ for 'Tombul', $0.34 \%$ for 'Palaz', $0.32 \%$ for 'Çakıldak' and $0.37 \%$ for 'Foşa' cultivars. Balik et al. (2016) reported palmitoleic acid contents as $0.10 \%$ for 'Tombul', $0.14 \%$ for 'Palaz' and 'Çakıldak', $0.11 \%$ for 'Foşa' and $0.06 \%$ for 'Allahverdi' cultivars.

Table 8. Palmitoleic acid (C16:1) in hybridization combinations in 2015 and 2016 (\%)

\begin{tabular}{|c|c|c|c|c|c|}
\hline \multirow{3}{*}{$\begin{array}{l}\text { Pollinator } \\
\text { cultivars }\end{array}$} & \multicolumn{5}{|c|}{ Main cultivars } \\
\hline & \multicolumn{5}{|c|}{2015} \\
\hline & Tombul & Palaz & Çakıldak & Foşa & Allahverdi \\
\hline Tombul & $1.68 \mathrm{~d}$ & $1.57 \mathrm{~b}$ & $2.67 \mathrm{a}$ & $1.30 \mathrm{~b}$ & $0.24 \mathrm{~g}$ \\
\hline Palaz & $1.63 \mathrm{e}$ & $1.50 \mathrm{~b}$ & $2.51 \mathrm{~b}$ & $1.73 \mathrm{a}$ & $0.96 \mathrm{a}$ \\
\hline Çakıldak & $2.62 \mathrm{a}$ & $1.70 \mathrm{a}$ & $0.69 \mathrm{f}$ & $0.28 \mathrm{~b}$ & $0.28 \mathrm{f}$ \\
\hline Foşa & $1.74 \mathrm{c}$ & $1.24 \mathrm{c}$ & $2.13 \mathrm{~d}$ & $0.75 \mathrm{~b}$ & $0.42 \mathrm{c}$ \\
\hline Allahverdi & $1.88 \mathrm{a}$ & $1.09 \mathrm{~d}$ & $0.71 \mathrm{f}$ & $0.35 \mathrm{~b}$ & $0.37 \mathrm{~d}$ \\
\hline Sivri & $1.72 \mathrm{c}$ & $1.54 \mathrm{~b}$ & $2.16 \mathrm{~d}$ & $0.16 \mathrm{~b}$ & $0.32 \mathrm{e}$ \\
\hline Kalınkara & $1.81 \mathrm{~b}$ & $* *$ & $1.78 \mathrm{e}$ & $0.10 \mathrm{~b}$ & $0.39 \mathrm{~d}$ \\
\hline \multirow[t]{2}{*}{ Yassı Badem } & $1.89 \mathrm{a}$ & $1.04 \mathrm{~d}$ & $2.32 \mathrm{c}$ & $1.27 \mathrm{~b}$ & $0.73 \mathrm{~b}$ \\
\hline & \multicolumn{5}{|c|}{2016} \\
\hline Tombul & $3.89 \mathrm{a}$ & $3.05 \mathrm{a}$ & $3.21 \mathrm{bc}$ & $2.31 \mathrm{a}$ & $0.27 \mathrm{f}$ \\
\hline Palaz & $3.05 \mathrm{~b}$ & $2.49 \mathrm{~b}$ & $3.05 \mathrm{c}$ & $0.34 \mathrm{~d}$ & $1.38 \mathrm{a}$ \\
\hline Çakıldak & $1.98 \mathrm{~g}$ & $2.54 \mathrm{~b}$ & $0.86 \mathrm{e}$ & $0.31 \mathrm{e}$ & $0.53 \mathrm{~d}$ \\
\hline Foşa & $2.25 \mathrm{f}$ & $2.20 \mathrm{c}$ & $3.70 \mathrm{a}$ & $0.82 \mathrm{c}$ & $0.47 \mathrm{~d}$ \\
\hline Allahverdi & $2.86 \mathrm{~d}$ & $2.41 \mathrm{~b}$ & $0.84 \mathrm{e}$ & $0.27 \mathrm{e}$ & $0.56 \mathrm{~d}$ \\
\hline Sivri & $3.01 \mathrm{~b}$ & $1.96 \mathrm{c}$ & $3.40 \mathrm{ab}$ & $2.43 \mathrm{a}$ & $0.77 \mathrm{c}$ \\
\hline Kalınkara & $2.92 \mathrm{c}$ & $3.14 \mathrm{a}$ & $2.74 \mathrm{~d}$ & $0.08 \mathrm{f}$ & $0.40 \mathrm{e}$ \\
\hline Yassı Badem & $2.64 \mathrm{e}$ & $2.15 \mathrm{c}$ & $3.29 \mathrm{bc}$ & $1.74 \mathrm{~b}$ & $1.22 \mathrm{~b}$ \\
\hline
\end{tabular}

*The means indicated with the same letter in the same column are not significantly different at $\mathrm{P}<0.05$. **: Data missing.

\section{Conclusions}

It has been determined that there are changes in hazelnut and kernel characteristics depending on the pollen sources. It was also observed in this study that pollinator cultivars resulted in significant changes in oil and protein ratios and fatty acid composition of hazelnut cultivars mostly because of xenia and metaxenia effects. Oil content and protein content changed depending on pollinator cultivars. Although varied with the treatments, in investigated hazelnut cultivars. While the oleic acid content was lower in the second year, greater values of the other fatty acids were observed in the second year. In self-pollination, generally more oleic and linoleic acid content was obtained, while a lower stearic acid content was found. As a result, it has been proven that pollinator cultivars change the biochemical content in hazelnut cultivation.

\section{Acknowledgements}

This study was supported by the General Secretariat of Black Sea Exporters Association and Hazelnut Promotion Group. Thanks are extended to Prof. Dr. Sami DOGANLAR of Molecular Biology and Genetics Department of İzmir High Technology Institute for his supports in fatty acid analyses.

\section{Authors' Contributions}

Huseyin Irfan Balik: Methodology, Investigation, Conceptualization, Validation, Review and editing. Neriman Beyhan: Methodology, Investigation, Conceptualization, Validation, Writing - original draft, Visualization.

\section{Conflict of interest}

The authors declare that they have no conflict of interest.

\section{References}

Anonymous, (2018a). Food and Agriculture Organization of the United Nations. http://www.fao.org/faostat/en/\#data/QC (Date of access: 31.01.2018).

Anonymous, (2018b). Hazelnut Research Institute Web Page.https://arastirma.tarim.gov.tr/findik/Sayfalar/Detay .aspx?SayfaId=29 (Date of access: 31.01.2018).

Ayfer, M., Uzun, A. \& Baş, F. (1986). Türk Fındık Çeşitleri. Karadeniz Bölgesi Fındık ve Mamulleri İhracatçılar Birliği Yayınları, 95, Ankara, Turkey.

Balik, H.I., Kayalak Balık, S., Beyhan, N. \& Erdoğan, V. (2016). Fındık Çeşitleri (Hazelnut Cultivars). Klasmat Matbaacılık, 96, Trabzon, Türkiye.

Balik, H.I, Beyhan, N. (2019). Pollen compatibility in Turkish hazelnut cultivar. Turkish Journal of Food and Agriculture Sciences, 1: 12-17.

Baysal, A. (1993). Genel Beslenme (8. Baskı), Hatipoğlu Kitabevi, 194, Ankara.

Beyhan, N. (2000). Fındığın Döllenme Biyolojisi. Ondokuzmayıs Üniversitesi Ziraat Fakültesi Dergisi, $15: 2,116-122$.

Bonvehi, J. S. \& Cool, F. V. (1993). Oil content, stability and fatty acid composition of the main varieties of Catalonian hazelnuts (Corylus avellana L.). Food Chemistry, 48:3, 237-241.

Botta, R., Gianotti, C., Richardson, D.G., Suwanagul, A. \& Sanz, C.L. (1994). Hazelnut variety organic acids sugars and total lipid fatty acids. Acta Horticulturae, 445: 319326.

Denney, J.O. (1992). Xenia includes metaxenia. Hortscience, 27:7, 722-728.

Dicenta, F., Martinez-Gomez, P., Ortega, E. \& Duval, H. 
(2000). Cultivar pollinizer does not affect almond flavor. Hortscience, 35: 1153-1154.

Dure, L.S. (1975). Seed formation. Annual Reviews, Plant Physiology, 26: 259-278.

Erdogan, V. \& Mehlenbacher, S.A. (1997). Preliminary results on interspesific hybridization in Corylus. IV. International Symposium on Hazelnut. 1 May 1997, ISHS Acta Horticulturae 445, 65-71, Ordu, Turkey.

Fatahi, R., Mohammadzedeh, M., \& Khadivi-Khub, A. (2014). Influence of different pollen sources on nut and kernel characteristics of hazelnut. Scientia Horticulturae, 173: $15-19$.

Focke, W.O. (1881). Die Pflanzen-Mischlinge:ein Beitrag zur Biologie der Gewachse. Bomtrae-ger, 510-518, Berlin.

Garcia, J.M., Ağar, İ.T., \& Streif, J. (1994). Lipid characteristics of kernels from different hazelnut varieties. Turkish Journal of Agriculture and Forestry. 18: 199-202.

Golzari, M., Hassani, D., Rahemi, M., \& Vahdati, K. (2016). Xenia and metaxenia in Persian walnut (Juglans regia L.). Journal of Nuts 7:2, 101-108.

Göncüoğlu Taş, N., \& Gökmen, V. (2015). Bioactive compounds in different hazelnut varieties and their skins, Journal of Food Composition and Analysis. 43: 203-208.

Kayahan, M. (1981). Beslenme ve insan sağlığı açısından bitkisel yağların önemi. Gıda, 6: 5, 23-30.

Kester, D.E., Cunningham, S., \& Kader, A.A. (1993). Almonds. Encyclopedia of foodscience, food technology and nutrition. Academic Press, 121-126. London.

Kirkpatrick, E.M. (editor) (1987). Chambers 20th century dictionary. New ed. Chambers, Edinburgh.

Kodad, O. \& Company, R.S. (2008). Fruit quality in almond as related to the type of pollination in self-compatible genotypes. Journal of American Society Horticultural Science, 133:3, 320-326.

Koyuncu, M.A., İslam, A. \& Küçük, M. (2005). Fat and fatty acid composition of hazelnut kernels in vacuum packages during storage. Grasas Aceites, 56:4, 263-266

Köksal, A.İ. (2002). Türk Fındık Çeşitleri. Fındık Tanıtım Grubu, 136, Ankara.

Mehlenbacher, S.A. (2014). Geographic distribution of incompatibility alleles in cultivars and selections of European hazelnut. Journal of the American Society for Horticultural Sciences, 139:2, 191-212.

Morris, W. (editor) (1976). The American Heritage Dictionary of the English Language. Hough Mifflin, Boston.

Navaschin, S. (1898). Resultat einer Revision des Befruhtusvorganger bei Lillium martagon und Fritillaria tenella Bul. de Academia Imp. de St.Petersbourg, 9:1-6.

Neufeldt, V. (editor) (1988). Webster's New World dictionary of American English. 3rd College ed. Webster's New World, New York.

Okay, A.N., Çalışkan, T. \& Çakırmelikoğlu, C. (1999). Fındık Genetik Kaynakları Projesi 'Allahverdi' Findık Çeşidinin Tanımlanması. Sonuç Raporu, Fındık Araştırma Enstitüsü.

Özenç, N., Özenç, D.B. \& Duyar, Ö. (2015). Nutritional composition of hazelnut (Corylus avellana L.) as influenced by basic fertilization. Acta Agriculturae Scandinavica, Section B-Soil- Plant Science, 64:8, 710721.

Pala, M., Açkurt, F., Löker, M., Yıldız, M. \& Ömeroğlu, S. (1996). Fındık çeşitlerinin bileşimi ve beslenme fizyolojisi bakımından değerlendirilmesi. Turkish Journal of Agriculture and Forestry, 20: 43-48.

Reiger, R., Michaelis, A. \& Green, M.M. (editor) (1976). Glossary of genetics and cytogenetics, classical and molecular. 4th ed. Springer-Verlag, Berlin.

Saura Calixto, F.J., Canelles Mut, J. \& Soler, L. (1988). La almendra: Composicion, variedades, desarrollo y maduracion. Instituyo Nacional de Investigaciones Agrarias, Spain.

Soule, J. (1985). Glossary for horticultural crops. Wiley, New York.

Strasburger, E. (1878). Uber polyembryonie. Zeitschr. für Naturwiss, 12: 654-678.

Swingle, W.T. (1928). Metaxenia in the date palm, possibly o hormone action by the embryo or endosperm, Journal of Heredity, 19: 257-268.

Şimşek, A. \& Aslantaş, R. (1999). Fındığın bileşimi ve insan beslenmesi açısından önemi. Gıda, 24: 3, 209-216.

Vezvaei, A. \& Jackson, J.F. (1995). Effect of pollen parent and stages of flower development on almond nut production. Australian Journal of Experimental Agriculture, 35: 109-113.

Vezvaei, A., \& Jackson, J.F. (1996). Almond nut analysis. In: H.F. Linsken, J.F. Jackson (editors). Modern methods of plant analysis. Fruit analysis. 18, Springer-Verlag, Berlin.

Westwood, M.N. (1989). Temperate-zone pomology. W.H. Freeman, 373-376, New York

Winburne, J.N.(1962). A dictionary of agricultural and allied terminology. Michigan State University Press, East Lansing, Michigan.

Xuhui, Z., Deyi, Y., Feng, Z., Xiaoming, F., Jing, T. \& Zhoujun, Z. (2016). A study on the xenia effect in Castanea henryi. Horticultural Plant Journal, 2:86, 301308.

Turkish Journal of Food and Agriculture Sciences is licensed under a Creative Commons Attribution-NonCommercialNoDerivatives 4.0 International License 